\title{
Same storm, different boats! The impact of COVID-19 on the wellbeing of school communities
}

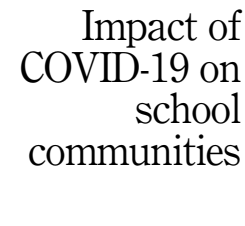

Catriona O’Toole

\author{
School of Education, Maynooth University, Maynooth, Ireland, and \\ Venka Simovska
}

School of Education (DPU), Aarhus University, Copenhagen, Denmark

\begin{abstract}
Purpose - The COVID-19 pandemic has impacted the functioning of education systems in a multitude of ways. In Ireland schools closed on March 12 th and remained closed for the remainder of the academic year. During this time educators engaged with students, families and colleagues in new and diverse ways. The purpose of this study was to explore educators' experiences during the closures, particularly regarding the impact of the pandemic on the wellbeing of students, school staff and wider school communities.

Design/methodology/approach - A series of one-to-one interviews, lasting approximately one hour, were conducted in July 2020 with 15 education professionals online via Zoom or Microsoft Teams. Participants occupied various roles (classroom teacher, school leader, special educational needs coordinator, etc.) and worked in a diverse range of communities in Ireland. Qualitative data from interviews were transcribed and emergent themes identified through an inductive followed by deductive analytic approach.

Findings - The interviews highlighted the central role that schools play in supporting their local communities and the value teachers place on their relationships with students and families. Many teachers and school leaders found themselves grappling with new identities and professional boundaries as they worked to support, care for and connect with the students and families they serve. There was considerable concern expressed regarding the plight of vulnerable or marginalised students for whom the school ordinarily offered a place of safety and security.
\end{abstract}

Originality/value - The findings reveal how COVID-19 has exacerbated pre-existing inequalities and the central role of schools in promoting the health and wellbeing of all its members.

Keywords Education, Schools, Covid-19 pandemic, Education professionals, Inequality

Paper type Research paper

\section{Introduction}

The emergence of coronavirus disease 2019 (COVID-19) has had a sudden and profound effect on schools and communities globally. The public health measures designed to curb the spread of the virus resulted in abrupt closures of schools, childcare, workplaces and community sporting and cultural activities. These mitigation efforts have not been felt equally across the population, but have interacted with existing patterns of inequality across dimensions of income, age, gender and ethnicity (Bambra et al., 2020; Marmot et al., 2020). For instance, a substantial number of children have no access to Internet, or live in homes in which there is no suitable place to do homework (OECD, 2020; Van Lancker and Parolin, 2020); thus, the loss of learning for children has been greatest amongst those from

(C) Catriona O'Toole and Venka Simovska. Published by Emerald Publishing Limited. This article is published under the Creative Commons Attribution (CC BY 4.0) licence. Anyone may reproduce, distribute, translate and create derivative works of this article (for both commercial and non-commercial purposes), subject to full attribution to the original publication and authors. The full terms of this licence may be seen at http://creativecommons.org/licences/by/4.0/legalcode

The authors wish to acknowledge the contributions of Yusuf Gahbiche and Abigail Watson, who's input into this project was funded by Maynooth University Summer Project for Undergraduate Researchers (SPUR).
Received 15 February 2021

Revised 24 June 2021

Accepted 18 July 2021 
$\mathrm{HE}$

122,1

economically and educationally disadvantaged backgrounds (Engzell et al., 2020; Jæger and Blaabæk, 2020).

Similarly, the disproportionate effects of COVID-19 on wellbeing and mental health have been documented (Lee, 2020; Marmot et al., 2020). Throughout the lockdown, cases of domestic violence escalated and there were surges in alcohol misuse within family homes, which placed children and young people at higher risk of exposure to violence and abuse. Save the Children (2020) noted that lockdown placed many families in a "pressure cooker" environment as a cascade of factors came together to increase family tensions, including the pressure of work and study at home, emotional and financial strain and the inability to grieve properly when a loved one dies. In Ireland, the Gardaí (Irish police) reported a 25\% increase in domestic violence calls in April/May 2020 compared to the same period in 2019 (Doyle, 2020). Over 20\% of adults said that their alcohol consumption had increased since lockdown, with the greatest increases reported amongst those living with children (27\%; CSO, 2020). The Irish Society for the Prevention of Cruelty to Children (ISPCC, 2020) reported a 100\% increase in visits to its website during the first lockdown, whilst children and families living in overcrowded and confined spaces (including asylum seeking families and Travellers) were more likely to contract the virus as well as experience increased levels of anxiety and isolation (NESC, 2021; OCO Ombudsman for Children's Office, 2020).

This evidence is illustrative of the stress and challenges experienced by children and families throughout the country. However, they do not reveal the whole picture as some children may not have the capacity or the opportunity to seek help. Furthermore, with schools and other services closed, the opportunities to spot signs, hear about children's experiences or make referrals for support, have significantly diminished (Baron et al., 2020). Nevertheless, it is clear both in Ireland and internationally that the psychological distress of children and young people who feel trapped or isolated at home is a very real issue and has the potential to become a greater problem than the virus itself (Hargreaves, 2020).

Education professionals have also been profoundly impacted by COVID-19. Before the pandemic, the level of stress and burnout amongst the teaching profession was already at worrying levels (e.g. Education Support, 2019; Fitzgerald, 2008; Foley and Murphy, 2015). Global patterns indicate the increasing complexity of teachers' roles and responsibilities following education reforms in many countries, and the intensification of principal's workload all of which is placing increased pressure on teachers and school leaders (Ontario Principal's Council, 2017; DNFA, 2018). The pandemic has added to these existing challenges. Teachers and school leaders were required to respond rapidly and with flexibility and creativity throughout this time of turmoil, at the same time as balancing personal commitments such as caring for and educating their own children and/or caring for vulnerable family members (Hargreaves and Fullan, 2020). Removing teachers from their usual work environments and asking them to work in new ways inevitably raises the question of what it means to be a teacher (Kim and Asbury, 2020). Furthermore, with more students experiencing stress and adversity, teachers' role in the provision of whole school wellbeing and mental health support also becomes more complex. All of this is likely to take a toll on the wellbeing of education staff, but also impact their professional identities and modes of engagement with teaching.

This study draws on theoretical perspectives underpinning the Health Promoting Schools (HPS) framework, which was first developed by the World Health Organisation in the 1980s. The HPS Framework adopts a holistic and salutogenic approach to promoting health and wellbeing in schools (Langford, 2014), highlighting the importance of attending to the full gamut of school structures and processes (curriculum, policy, relationships and partnerships, emotional climate, etc.). Researchers and scholars in this field have moved beyond a narrow focus on individual skills and behaviours, to explore socio-cultural and other contextual factors that influence health and wellbeing (Leahy et al., 2020; Simovska and McNamara, 2015). This framework prompts the need to consider the determinants of wellbeing during the pandemic, 
including the various adversities, traumas, stresses, resources and supports that exist for members in particular school communities. It also suggests considering wellbeing of school communities in a holistic way, rather than focusing on teacher or student wellbeing separately.

With this framework in mind, we sought to explore education professionals' experiences during the first lockdown in Ireland (March-June 2020), particularly their perspectives regarding the impact of the pandemic on the wellbeing of students, school staff and wider school communities. As argued by Lupton (2020), despite the difficult conditions related to conducting research during the pandemic, social research is urgently needed to explore and document people's everyday experiences of living during a global health crisis. Educational researchers can contribute to understandings of how schools communities have been affected by living in the pandemic and to shaping educational responses occurring now and in a postCOVID world. Thus, in researching how COVID-19 affected the wellbeing of teachers, students and the school community in Ireland, we were interested in exploring the diverse realities of various groups and the implications for school wellbeing efforts now and into the future.

\section{Methodology}

Semi-structured interviews were carried out with 15 education professionals across various schools throughout July 2020. A theoretical sampling frame (Given, 2008) ensured a diverse range of educational professionals and school settings were captured. Participants were recruited through social media fora and professional networks. We sought to ensure participants represented important dimensions of variation in school composition and organisation, particularly in terms of school sector, size, gender, social mix and geographical location. This allowed us to capture the experiences and challenges across diverse school settings. Nevertheless, owing to the short timeframe for data collection, the final sample included more participants from primary vs secondary school contexts.

As shown in Table 1, the sample consisted of seven males and eight females occupying various professional roles in education. Seven participants worked in schools that are

\begin{tabular}{|c|c|c|c|c|c|}
\hline Pseudonym & Gender & Main role in school & School level ${ }^{\mathrm{a}}$ & $\begin{array}{l}\text { DEIS/Non- } \\
\text { DEIS }^{\text {b }}\end{array}$ & Mix \\
\hline Aryanna & Female & Classroom Teacher & Primary & DEIS & Mixed \\
\hline Jack & Male & Director of alternative school & Secondary & - & Mixed \\
\hline Sam & Male & Classroom Teacher & Primary & DEIS & Mixed \\
\hline James & Male & Classroom Teacher & Secondary & DEIS & Girls \\
\hline Shauna & Female & $\begin{array}{l}\text { Special Educational Needs } \\
\text { Coordinator }\end{array}$ & Secondary & Non-DEIS & Mixed \\
\hline Mary & Female & Principal & Secondary & DEIS & Mixed \\
\hline Chris & Male & Classroom Teacher & Secondary & Non-DEIS & Mixed \\
\hline Grainne & Female & Classroom Teacher & Secondary & Non-DEIS & Boys \\
\hline Michelle & Female & Principal & Primary & Non-DEIS & Mixed \\
\hline Philip & Male & Deputy Principal & Secondary & Non-DEIS & Boys \\
\hline Colin & Male & Principal & Secondary & DEIS & Mixed \\
\hline Sandra & Female & Classroom Teacher & Secondary & Non-DEIS & Girls \\
\hline Saoirse & Female & School Guidance Counsellor & Secondary & Non-DEIS & Mixed \\
\hline Sophie & Female & School Completion Co-ordinator & Secondary & DEIS & Mixed \\
\hline Patrick & Male & Home School Liaison Co-ordinator & Secondary & DEIS & Mixed \\
\hline
\end{tabular}

Note(s): ${ }^{\text {a }}$ Primary schools cater for children aged 4-12 years; secondary school cater for the 12-18 year-old age group

bEEIS (Delivering Equality of Opportunity in Schools) denotes those schools who qualify for entry into the DEIS scheme, a government-funded scheme that provides additional resources for schools with high concentrations of students from socioeconomically disadvantaged backgrounds (DES, 2005)

\section{Impact of COVID-19 on school communities}


$\mathrm{HE}$

122,1

designated as disadvantaged (DEIS). One participant reported being of Asian ethnicity, everyone else identified as White Irish. There was a fairly good geographical spread (three schools from Dublin and three from other Eastern counties, two from western counties, five from the south and two from northern regions of the country). No Irish-medium schools, feepaying schools or special schools were included. Despite a relatively small sample size, previous research has shown that it is possible to ensure a good deal of variation by drawing from participants in as few as 10 schools (McCoy et al., 2014).

Interviews were conducted online using MS Teams and lasted 40-60 min. They were recorded, with consent, and the anonymity of participants and schools was ensured. Research ethics guidelines were followed and ethical approval for the study was obtained from Maynooth University Social Science Research Sub-Committee. The interviews were transcribed verbatim and analysed using a hybrid approach, which incorporated a data-driven inductive process based on Braun and Clark's (2006) analytical model, followed by a deductive process, whereby a pre-existing framework (in this case the HPS Framework) was applied to the data (Crabtree and Miller, 1999). This process allowed for themes to initially emerge from the data and in turn, for the theoretical concepts to shape the themes, which we outline in the next section.

\section{Findings}

A number of themes emerged from our analysis. We discuss these below, starting with the themes relating to students and continuing with the themes relating to educators. We round off the discussion of findings by considering the lessons learnt in terms of school development.

\section{Rising to the challenge: young people taking up new roles and responsibilities}

Participants in the study expressed admiration for how children and young people were responding to the pandemic. According to the interview accounts, many young people had taken on additional work or care responsibilities within the family during lockdown, such as looking after younger siblings so their parents could continue working, or helping with agricultural work. Some young people "moved in with grandparents, so that their grandparents had some able-bodied person there to help them" (Philip, deputy principal, secondary school), others supported their local communities by "delivering supplies to cocooning elderly" (Grainne, secondary school teacher).

At the same time, concern was reported about the burden young people were shouldering. Grainne, a secondary teacher, described one of her students, "a high achiever", whose parents were both healthcare workers:

he was doing his damndest to try and get all of his [school] work done ... whilst also having to decovid the house because his parents were working in a really infected zone. It was just surreal, you know, what these teenagers are having to deal with.

Participants were also critical of the way in which young people were often singled out and blamed for their "irresponsible" behaviour in certain sections of the media: "Some of the [media] messaging being sent out was absolutely horrendous. For kids who already think very little of themselves, to be telling them somehow they were gonna be the vectors, that are gonna kill their grandparents" (Jack, director, alternative school). Evidently, the professionals put themselves on the side of their students, acknowledging the efforts children and young people made to cope with the lockdown, support their families and maintain their self-worth in the face of negative public discourse.

Adversity, marginalization and psychological distress among students Whilst some students were faring well, the education professionals we talked to recounted the various challenges that many were dealing with. Many students were worried about school 
work, exams and about family members; some students were extremely isolated, "they don't leave the house" or "hadn't been outside the door in six weeks". Many study participants spoke of their concerns for students that they lost touch with, "kids that were really affected by remote learning - who didn't really engage at all" (Saoirse). There was particular concern for children with additional education needs, disabilities and mental health difficulties who had lost access to professional support. The study participants also voiced concerns about regression in learning, particularly for students who learn English as an additional language.

Some study participants detailed the psychological toll school lockdown had, especially on students living in marginalized communities and those with histories of trauma and adversity. Issues like self-harm, suicide, domestic violence, neglect, substance misuse and violence were highlighted. For instance, Jack, a director of an alternative school, confided that "I worry, I really do worry ... over this period I had one young person who had tried to take her own life ... ehm ... I had three young people self-harming ..." In a similar vein, Grainne was aware that one of her students has been used as a "drug mule", another has self-harmed. She felt that "the biggest issue for my students would be ... that they get involved in drugs or they get involved in robbing".

Patrick (a home-school-community liaison co-ordinator) reported that a school he works with had experienced the death of a former student by suicide. He expressed concern about the possibility of suicide contagion in the community and the challenges that school closures posed for identifying students who may be vulnerable:

If a student passes away in the school, you have to start looking at our student's level of vulnerability and if they are at risk because of it ... It was more difficult when we weren't as a team face to face. It was more difficult to work out circles of relationships - which students were cousins, friends, close neighbours of the deceased young person-when we weren't in the same room.

While in normal circumstances the school would be attentive of the potential risks and take action to ameliorate them, in the lockdown this was very difficult, if not impossible. In addition to the increased risk for the students, this situation also raised the level of stress experienced by professionals.

Principals were cognisant that in the course of a normal school year they would make a number of child protection referrals. They were concerned about children experiencing neglect or abuse who may be missed due to school closures, but also about the potentially increased number of children experiencing such adversities, due to the pandemic itself.

I think everyone was pushed to limits here during this time, and so, whether that brought out, maybe violence in the home ... or neglect ... [When schools reopen] I'm going to have my child protection eyes on at a magnitude I've never had before. (Michelle, primary school principal)

The professionals we interviewed working in marginalised communities were acutely aware that the school functions not just as a place for learning, but also as a safe place - a sanctuary - for many children and young people. The citation below is illustrative for this point:

And for so many of them, that is their safety net, you know. They come for school, because they're minded, and they're looked after, and they feel safe, and they feel secure, and it's their safe place, you know ... They will stay there till six o'clock in the evening sometimes. And, em, I dread to think what's happened to some of them, I really do. (Grainne, secondary teacher).

This theme clearly extends the previous one and shows the devotion, care and concern professionals experienced for students during the lockdown. The accounts demonstrate that the lockdown disrupted the regular work of school, not only in terms of teaching and learning but also concerning child protection and wellbeing. This, as the further discussion of the findings will demonstrate, resulted in increased levels of concern and stress among the professionals.

Impact of
COVID-19 on
school
communities 
$\mathrm{HE}$

122,1

\section{Teaching and learning in a virtual classroom}

The study participants used various platforms to facilitate online learning. Only one participant (Sandra) reported providing fully synchronous online classes in line with the school's pre-pandemic timetable. Most teachers provided a blend of synchronous classes, prerecorded classes and online support. The analysis showed that according to the professionals interviewed, online teaching presented challenges for everyone - teachers, students and families. Firstly, the "digital divide" was frequently mentioned. Some regions in the country (particularly rural areas) have poor connectivity to broadband which posed problems for students and teachers alike. The pictures sketched in the interviews were vivid; one principal described a student "[.. .] outside in the yard walking around with his hand up in the air - his phone up in the air, trying to get signal to send an email with work to a teacher" (Philip). Another school principal talked about "a teacher who had to go to her father's house every day to do her teaching, because her own house didn't have good enough internet connection" (Mary). In addition, students from poorer families often did not have access to devices at home, or they had to share IPad or laptops with siblings and parents, which prevented them from engaging fully in online learning, and in some cases, was a reason for conflicts and tensions in the family.

Secondly, the analysis showed that synchronous classes were problematic because, according to participants, some of the students did not feel comfortable making visible their private space to others in the class. Mary, a secondary school principal highlighted that:

[... ] many kids don't want to be seen on camera, they're worried what else will be seen on camera, apart from themselves yknow. In a school like ours, where there would be some kids living in extreme poverty, and I can imagine that they would not want that seen, and that they were worried about it ...

Evidently, issues of inequality took a different shape as private space became part of the online classroom. In some cases, vulnerability, shame and other feelings of discomfort prevented students from engaging in teaching and learning.

Thirdly, the analysis pointed to vulnerability of teachers too, especially in second-level schools. A recurring theme was concern about the potential manipulation and sharing of images and recordings by students. The following citations are representative for these concerns:

There were videos being made of teachers and other students that were being shared in Snapchat and all of that. Therefore, the school advised teachers "if you do wish to do a Zoom class - which you don't have to, but if you do, that's fine-turn off your own video. If you're demonstrating something, that's fine, but don't have your own face visible. (Philip, deputy principal, secondary school)

In this case, the teachers were advised not to have their video turned on during the class, which may have had a negative impact on students' engagement during the session. In another example below, a principal describes the wariness of his colleagues/staff.

Not all teachers are comfortable with the idea of recorded lessons or live lessons going out to students that are at home. A few teachers are concerned about how images of themselves and recordings of themselves being used and put up on social media. (Colin, secondary school principal)

This points to additional stress factors for teachers related to online teaching. As well as being concerned about their students, they had to cope with increased personal exposure and vulnerabilities that online teaching brought. In some cases, as the excerpt below shows, the distress was quite high, and based on specific experience.

[...] so it would have been the usual heads cut off bodies and stuck on porn. Or, 'I've got mental health problems', you know, they'd have these speech bubbles out of the teachers' mouths. Some teachers will come in for a lot more stick than others, but generally it was, either they were mentally 
deficient or they were, you know, stupid or backward, or else they were young and good-looking. And obviously from being in a boys school, in that context, there obviously is going to be ..., em females are going to get the brunt of that. And a few of them have had, em, a terrible time ... And, em, you know, I've seen footage of myself being manipulated, and stuff like that. And there's nothing you can do about it. In fairness to my school, they have done an awful lot to clamp down on that. But I think putting up live footage of you teaching is really just asking for trouble, particularly in my context. (Grainne, secondary teacher)

The excerpt points to difficult experience of being a female teacher working in boys' school, but Grainne also described homophobic bullying targeted at a young male teacher in the school. Despite the efforts of the school leadership to prevent such behaviours, teachers felt vulnerable and under a lot of stress.

Finally, educators emphasised the fundamental educational value of face-to-face communication and relationships between students and teachers:

Staff definitely want to get back into the classroom. It's the natural way for them, and I suppose that relationship is so crucial to education generally, isn't it? Like, one-to-one and face-to-face. (Colin, secondary school principal)

The extract above highlights the decisive role direct contact between teachers and students plays in education. Face-to-face contact was deemed especially crucial for younger children and those with special educational needs. It was also evident from the interviews that many participants missed the cut and trust of everyday face-to-face interactions with students and families:

Get me back in the classroom! I do not want to do blended learning in September; that is just hell on earth. It's awful. I really, really hated it, and d'you know, there was actually one or two days where I got a bit upset - it was bizarre. I remember being just like, oh, I really miss them. You know, and they're lovely boys ... (Grainne, secondary teacher)

The excerpt above is illustrative of the passion and emotional connection of teachers related to being physically present with students along with the dynamism of the classroom that the online world simply could not replace. Related to this was teachers reporting feelings of inadequacy and guilt because they could not be physically present for their students. It seems that although educators took up the challenge of organizing meaningful teaching by using available digital platforms, there were challenges and significant discomfort for students and teachers alike. In addition, it is evident that in the professionals' views, the totality of experience of being an educator cannot be fulfilled without physical presence, face-to-face contact and an embodied relationship with students.

\section{Navigating new professional boundaries}

Given the changes in work practices, many study participants found themselves navigating professional boundaries in new ways. Some teachers reported responding to student emails at all times of day and night, some principals gave parents their personal mobile phone number to ensure they were accessible. Many teachers in marginalised communities described efforts to maintain contact with their students, such as visiting family homes and sending educational resources by post. Teachers that provided synchronous lessons reported a new sense of informality, which required a greater level of negotiation of boundaries between teacher and students.

When you teach synchronously, you are, for the most part, in your students' bedrooms, which is exceptionally private. You know, like they're teenagers - there are some of them who, you know, are a bit too vulnerable for that. You are, you know, invading their personal space, and they are for you also .... (Sandra, secondary teacher)
Impact of
COVID-19 on
school
communities

(1)


$\mathrm{HE}$

122,1

While the accounts discussed earlier illuminated the teachers' feeling of vulnerability, the excerpt above describes the vulnerability of students, and the need to renegotiate personal space in the relationship between teachers and students.

Another teacher we interviewed, Aryanna, works in a primary school where many students live in Direct Provision accommodation. Direct Provision is a system used in Ireland to cater for the basic needs (shelter and food) of asylum seekers while their claims for refugee status are being processed (it has been criticised as being inhumane and degrading by human rights organisations). Aryanna described supporting the mother of one of her students, who was extremely distressed about a situation that "had nothing to do with school, had nothing to do with me, had nothing to do with the kids, but ... I couldn't, as a mother, as a human being, I couldn't do nothing", because the families' application for asylum in Ireland may have been in jeopardised if the situation wasn't resolved. Aryanna also described her concern for the children who were witnessing their mother's extreme distress within the confined space (a single room) that was available to them. Evidently, this teacher describes the need to redefine professional boundaries in time of extraordinary crisis and engage as a (political) human being. She reflected:

I think in one sense, that blurring of the boundaries ... I think that's a really beautiful thing. It's a piece of humanity, that quite frankly, having worked all over the world, I see as missing a little bit in some Irish teachers ... in that attempt to make that very clear delineation between us and them.

Working from home also meant that participants had to navigate new work/life boundaries; these related not only to juggling work and home responsibilities but also efforts to ensure confidentiality and to protect their own families from hearing about workplace issues. Sophie works on a School Completion Programme to support students at risk of early school leaving and their families. She reported:

There's no distance from where I am now to where my children are. It really difficult to hear the stuff we hear... When you work in this area, you protect your family from what happens in work so that they don't know that stuff. But when there's the potential for you to be heard on the phone, when you're trying to have a support call for a family in chaos ... it's really challenging.

The concern expressed above goes both ways - it is about guarding the confidentiality of the students and their families and about protecting one's own family, especially children, from the hardships experienced by other people and the worries that this may evoke.

In summary, the accounts in this theme point to the deep commitment of education professionals to the students and families they work with, and readiness to redefine professional boundaries with a view of providing support for those who needed it the most in the midst of the crisis. In some cases, the professionals struggled to ensure that their commitment does not expose their own families to increased stress and worry.

\section{Lack of adequate governance}

Nearly all participants expressed dismay and frustration at the way in which the state Department of Education (DES) communicated with schools. It is evident from the interviews that on a number of occasions the Department issued directives, known as "circulars" to schools on Friday afternoons, which caused considerable frustration as the following interview excerpts highlight:

There was this pattern of dropping circulars on a Friday evening” (Chris, secondary teacher).

The Friday evening thing! We came to such a stage that I used to have to say to people, you know, I'm just going to have to keep Friday afternoon completely free, because something is probably going to come from the Department and I'm going to have to get it out to the parents. (Mary, secondary school principal) 
Participants also expressed irritation about guidance for online learning that arrived too late - "like, two months after we'd been at the cold face" (Chris). In addition, professionals were extremely frustrated that DES announcements were often issued or leaked to the media in the first instance. The two interview excerpts below are illustrative for these experiences.

But the media would have had announcements. The Irish Times (newspaper) would have broken some story or another .... like, I saw it on Twitter. It hadn't been emailed to me. It hadn't been notified to me any other way. And I think that's a real insult to the good work that's being done in schools (Philip, deputy principal).

Information is kinda leaked first and then you've parents panicking. So, like, I had to send out, you know, a holding text to parents, 'cause I knew they were worrying, to say, look, you know, we've heard that this is happening and will notify you as soon as we get information. (Mary, principal)

The lack of adequate governance and consultation was insulting to educators, increased their stress levels, but also their sense of responsibility towards parents. Evidently, all of this had a deleterious impact on staff wellbeing and their sense of public support in extraordinary circumstances. The study participants felt that parents and teachers were being pitched against each other and that the manner in which the DES communicated contributed to "teacher bashing" in the media. The overwhelming view of school personnel was that far from supporting schools, the national authorities added unnecessarily to the workload and stress of all education stakeholders, especially school leaders.

\section{The importance of solidarity and school leadership}

The analysis pointed to an increased sense of camaraderie and community between colleagues. An emerging theme is in the interviews was awareness that colleagues' personal circumstances varied; that "everyone's in a different place". Many study participants expressed that they missed the informal conversations with colleagues and other moments of social connection, mutual inspiration and support:

Like, there's nothing better than bouncing ideas off others, and that was one of the things I missed about school, you know when you're going down the corridor and you have an idea, and you go all whacky! (Michelle, primary school principal)

The analysis showed that school leaders expressed appreciation for their staff, most of whom were going "way beyond the call of duty", but they were also concerned for their wellbeing. Colin, a secondary school principal, stated his staff "couldn't rest if they thought that some students were finding work difficult, and they had to check on them". Similarly Mary reflected:

I've just so much admiration for how quickly they came on board, not everyone now obviously but the vast majority ... Generally for me, I think what they needed a lot was reassurance that what they were doing [was ok] ... I certainly would've had worries for the wellbeing of some of my teachers because they were going over and above what was required. (Mary, secondary school principal)

Evidently, principals recognised and appreciated the work of their teaching staff, the burden teachers carried in terms of their teaching role, but also in caring for students and families during the lockdown.

In relation to their own workload, principals spoke about the support they received from other school leaders, the school board of management, and other, mostly informal networks:

There's no doubt about it, there is a brilliant support network [amongst] principals themselves, and it was a very valuable safety net to have ... everyone is very honest and open about their issues, so ... those meetings were very supportive, you know. (Mary, secondary school principal)

Nevertheless, while principals tended to be stoical about the challenges and uncertainty they were facing, the analysis pointed to a massive concern about the reopening of schools,
Impact of
COVID-19 on
school
communities 
$\mathrm{HE}$

122,1

56

especially the responsibility they carried for ensuring the health and wellbeing of their staff and students. Some reported that their school buildings are "not fit for purpose", with narrow corridors and small classrooms, inappropriate for social distancing. Further, principals were worried about possible staff shortages; they predicted problems securing substitute teachers in the event that core staff took ill. Other concerns related to whether the state would provide sufficient resources for cleaning, sanitising and for personal protective equipment. They expressed concern for Special Needs Assistants most of whom are involved in "close contact personal care." One participant flagged that there is "massive stresses on school leadership, everything is so up in the air"; another anticipated that "school principals are all going to be sick by November".

\section{Silver linings?}

Many study participants noted there were certain positive aspects to the lockdown. These included spending more time with family, rediscovering possibilities for outdoor physical activity and new ways of coping with the lockdown, as illustrated in the citation below.

There is a newfound respect among students, or appreciation among students and young people now for the simpler things in life, for being at home, and being with family, and having to get on with your family. Even the whole physical aspect to wellbeing - I know a shop-owner here, he sells bikes and he said, in the three months after the pandemic, of lockdown, he sold 2,000 bikes. (Colin, secondary school principal)

It is notable, however, that the possibilities for outdoor pursuits were not flagged by participants working in marginalised areas. On the contrary, these participants highlighted that many families were living in communities where there was a lot of anti-social behaviour, violence or outdoor alcohol consumption. In this context parents had little option but to keep their young children indoors where they could ensure their safety. According to Michelle (a primary school principal), "One mammy reported that she wasn't allowing the children outside at all. So, even though the weather was beautiful, she said it's safer for the children to be inside".

Another positive aspect identified through the analysis of the interviews related to "lessons learnt", which could potentially lead to change in educational policy. For example, one participant felt that the pandemic provided an opportunity to reform the Leaving Certificate (high stakes, state examination at the end of the Senior Cycle, second-level education), however he was not overly optimistic:

I think that what has happened now should feed into what the new Senior Cycle is going to look like ... [I'm] concerned, that when things do return as normal as possible, we're just going to go back to the way we were. And, you know, racing about everywhere ... and time isn't here for this or that. I think in general, not just in school, we have to appreciate, that life isn't a big race. (Colin, secondary school principal)

Some teachers found that the different pace and place of working provided them with time to reflect on their values and professional identity, as the extract below highlights:

You would find yourself looking out the window and thinking, yknow, who am I as a teacher? What do I value? Am I doing enough here? When Covid hit and schools closed, I realised, okay, let's go back to the bigger picture here ... let's think about what's important again. (Sam, primary teacher)

In a similar vein, teachers expressed the benefits of the increased need to develop their professional capacities and competences. It's made pedagogical practices much more exciting, just to be learning again .... I really hope that that positivity of the skills and the pedagogical practices that have changed will move forward with us, and we'll have gained a lot from it. (Sandra, secondary teacher) 
Others simply enjoyed the working from home experience and found they got more done, as there were fewer interruptions. Grainne (secondary teacher) felt her stress levels reduced and she slept better:

[...] and bizarrely, I was sleeping so much better, my stress levels plummeted, and it was just ... I remember thinking, "wow, I've slept!' 'Cause when I'm working, I don't really sleep . . . I've definitely seen the lines on my face reduce, yknow, the bags under my eyes-gone!

There were some benefits reported for students as well, Colin, a secondary school principal, reported that "the freedom and the flexibility to work within their own constraints at home suits some students. But that's a minority".

\section{Discussion}

The pandemic and resulting school closures have had an enormous impact on the wellbeing of the school community. Our study highlights that education professionals were deeply engaged and devoted to students and families they worked with, sometimes with the cost of increased stress, vulnerability or concern for themselves or their own families. They acknowledged the resilience of students, in times when most of the public discourse tended to demonise young people or cast them as careless and egocentric. Furthermore, education professionals were fully aware that while we are all in the same storm of the pandemic, not everyone is in the same boat. Concern about inequalities and a desire to support the most vulnerable students was evident in the interview accounts. At the same time, the professionals did not feel sufficiently acknowledged and supported themselves, particularly by central education authorities. They did, however, report the vital significance of collegial solidarity and support.

In line with predictions of other authors (Darmody et al., 2020; Van Lancker and Parolin, 2020), this study revealed that school closures were disproportionately affecting those already marginalised by society. Most recurrently reported challenges for students were isolation, worry, loneliness, self-harm and suicide. Concern about student using drugs and being lured into crime gangs were also expressed. Educators were especially concerned for students living in challenging circumstances, including asylum seeking children living in emergency accommodation, those exposed to adverse and traumatic experiences (such as poverty, neglect and violence), students with additional educational needs and those at risk of substantial loss of learning, school refusal and drop-out.

Educators went to great lengths to connect with students and families. Previous surveys in Ireland have found that during the first lockdown the majority of schools put measures in place to contact student daily or every other day, with schools relying mainly on email and various online platforms (Burke and Dempsey, 2020). However, this study shows that many educators, particularly those serving marginalised students, had to find new and more imaginative ways to maintain contact with students. This included visiting family homes, delivering educational resources and messages by post and regular phone calls. It was clear that an ethic of care and desire to sustain relationships were central driving forces in these endeavours.

The study highlighted that schools are a staple in their communities and offer a lifeline for many students. They provide a space, not just for learning and intellectual stimulation, but also a place of safety, connection, predictability and routine. This study provides evidence of the collective resilience, resourcefulness and sense of solidarity that exists within school communities. However, it raises inevitable questions around what is expected of schools vs what is feasible for them, given available resources. With evidence of increased distress and trauma experienced by children during the pandemic, it is clear that schools will need greater awareness of trauma and how it impacts students' lives. In addition, it is well known that professional working with children who experienced adversity tend to report high levels of compassion fatigue, secondary traumatic stress and burnout (Howard, 2019), which can

Impact of
COVID-19 on
school
communities 
$\mathrm{HE}$

122,1

compromise their capacity to provide empathetic responses to students in their care, and is distressing for teachers in its own right. Given the challenges of the pandemic there is a pressing need to move beyond paying lip service to teacher wellbeing. Resources to support whole-school trauma-informed approaches will be crucial in this regard, in order to create the conditions that enable both students and staff to flourish (O'Toole, in press).

The shift to remote teaching has disrupted and altered the nature of interpersonal connections that teachers have with students, families and colleagues. Similar to Kim and Abrey (2020) we found that this shift affected teachers professional identify and for some prompted a re-evaluation of core values. Teachers in our study were navigating new ways of working, new professional boundaries and reflecting on what it means to be a teacher. They overwhelmingly expressed a desire to return to face-to-face teaching, acknowledging the importance of physical presence and embodied relationships, both for their students' wellbeing, but also for their own job satisfaction, meaning and purpose (Spilt et al., 2011).

In addition to re-evaluating their professional identity, educators were forced to adapt their current ways of working often without sufficient resources, training or support. They expressed a range of feelings including vulnerability, guilt and worry, which were often evoked by reflecting on the plight of their students/families. Sexual harassment and homophobic bullying of teachers by students was another issue that was raised, and whist this issue has surfaced in previous research (O'Toole et al., 2018), it remains an under researched area.

There were also considerable pressures on school leaders, who at the time of interviews were bracing themselves for the colossal challenge of keeping Covid out of their schools and keeping their communities safe. Harris (2020) noted that school leadership during a crisis is exhausting and incessant work. While the school leaders we spoke to were responding positively and stoically to the crisis, the pressures on them were deemed unhealthy, unsustainable and very likely to have a detrimental impact on school wellbeing going forward, a finding echoed by Dempsey and Burke (2020).

There was a deep sense of anger and frustration in relation to the state Department of Education. The lack of adequate governance, collaboration and involvement was deemed to be an insult to the good work being done in schools; it undermined relationships between teachers and families, and increased the workloads and pressures on school leaders. The wellbeing of students and teachers are profoundly intertwined (O'Toole and Simovska, in press). In this time of turmoil and uncertainty, the priority for wellbeing must extend to school leaders and teachers, as well as students (Harris and Jones, 2020). Enhanced support, meaningful collaboration and compassionate leadership from the Department of Education could substantially enhance the wellbeing of teachers and school leaders. In addition, teachers may benefit from professional supervision (as is available to other frontline professionals, Lawrence, 2020); a system that would that allows them to share some of the distressing encounters their job entails with a trusted colleague so they can be emotionally and practically supported at a time when their role is harder than ever.

In summary, our findings support the need for reimagining and re-positioning education in a post-pandemic world, rather than merely returning to the way things were. COVID-19 presents an opportunity to take what we know about the universal human needs for safety, belonging and social connection and to "build back better" (PSC, 2020). In relation to educational equality, this means developing educational policies in which values of participation, inclusion, community and trust are prioritised over individualism, accountability and competition. In the Irish context, COVID-19 has shed light on how certain groups of children are placed at risk of neglect, abuse and other harm due to structural inequalities; it has also revealed educational incongruities, such as the dangers of relying on high stakes, summative examinations that generate high levels of stress and anxiety for students and their families (Smyth et al., 2019) and increasingly for teachers as well (Devenney and O’Toole, 2021). 
As noted earlier, one of the educational frameworks that acknowledges the intersection of wellbeing and education, is the Health Promoting Schools framework, or the so-called settings approach to health and wellbeing promotion in schools (WHO, 1998; Simovska and McNamara, 2015; Saboga-Nunes et al., 2020). Indeed this framework partly informs Ireland's wellbeing policy for schools (DES, 2019). The findings of this study reassert the need for whole-school approaches, in which wellbeing is embedded in all aspects of school life (relationships, policies, culture and curriculum). However, they point to the need for greater focus on the social determinants of emotional and psychological distress, enhanced support for trauma-informed approaches and more compassionate/collaborative leaderships from the state. This would support the collective resilience of schools, enabling them to respond to the pandemic flexibly, safely and in equitable ways, as they work to sustain - or even transform their core purpose in response to crisis situations (Simovska, 2020).

\section{References}

Bambra, C., Riordan, R., Ford, J. and Matthews, F. (2020), "The COVID-19 pandemic and health inequalities", Journal of Epidemiological Community Health, Vol. 74 No. 11, pp. 964-968.

Baron, E.J., Goldstein, E.G. and Wallace, C.T. (2020), "Suffering in silence: how COVID-19 school closures inhibit the reporting of child maltreatment", Journal of Public Economics, Vol. 190, p. 104258.

Braun, V. and Clarke, V. (2006), "Using thematic analysis in psychology", Qualitative Research in Psychology, Vol. 3 No. 2, pp. 77-101.

Burke, J. and Dempsey, M. (2020), Covid-19 Practice in Primary Schools in Ireland Report, Maynooth University Department of Education, available at: https:/www.into.ie/app/uploads/2020/04/ Covid-19-Practice-in-Primary-Schools-Report-1.pdf.

Crabtree, B.F. and Miller, W.L. (Eds), (1999), Doing Qualitative Research, 2nd ed., Sage Publications, New Jersey.

Central Statistics Office CSO (2020), "Social impact of Covid-19 survey", available at: https://www.cso. ie/en/releasesandpublications/ep/p-sic19/socialimpactofcovid-19surveyapril2020/.

Darmondy, M., Smyth, E. and Russell, H. (2020), The Implications of the Covid-19 Pandemic for Policy in Relation to Children and Young People: A Research Review, Economic and Social Research Institute, Dublin.

Dempsey, M. and Burke, J. (2020), Covid-19 Practice in Primary Schools in Ireland Report: A Two Month Follow-Up, Maynooth University Department of Education, available at: http://mural. maynoothuniversity.ie/13001/.

Department of Education and Skills (2005), "Delivering equality of opportunity in schools) an action plan for educational inclusion", available at: https://www.education.ie/en/Publications/PolicyReports/deis_action_plan_on_educational_inclusion.pdf.

Department of Education and Skills (2019), "Wellbeing policy statement and framework for practice", available at: https://www.education.ie/en/Publications/Policy-Reports/wellbeing- policystatement-and-framework-for-practice-2018\%E2\%80\%932023.pdf.

Det Nationale Forskningscenter for Arbejdsmiljø (Danish Research Centre for Workplace Environment) (2018), FTF'ernes psykiske arbejdsmiljø - hovedresultater og konsekvenser for sygefravar Og sygenarvar (Psychological Workplace Environment - Key Findings and Consequences in Terms of Sickness and Sick Leave), Copenhagen.

Devenney, R. and O'Toole, C. (2021), "What kind of education system are we offering': the views of education professionals on school refusal", International Journal of Educational Psychology, Vol. 10 No. 1, pp. 27-47, ISSN 2014-3591.

Doyle, J. (2020), Domestic Violence and Covid-19 in Ireland, Oireachtas Library \& Research Service, available at: https://data.oireachtas.ie/ie/oireachtas/libraryResearch/2020/2020-06-09_1-rs-notedomestic-violence-and-covid-19-in-ireland_en.pdf.
Impact of
COVID-19 on
school
communities 
$\mathrm{HE}$

122,1

Education Support (2019), Teacher Wellbeing Index 2019, available at: https://www.educationsupport. org.uk/resources/research-reports/teacher-wellbeing-index-2019.

Engzell, P., Frey, A. and Verhagen, M.D. (2020), "Learning inequality during the COVID-19 pandemic", available at: https://ideas.repec.org/p/osf/socarx/ve4z7.html.

Fitzgerald, B. (2008), "Teachers and workplace stress", Astir, Vol. 26, pp. 17-18.

Foley, C. and Murphy, M. (2015), "Burnout in Irish teachers: investigating the role of individual differences, work environment and coping factors", Teaching and Teacher Education, Vol. 50, pp. 46-55.

Given, L.M. (2008), The SAGE Encyclopedia of Qualitative Research Methods, Sage, Thousand Oaks, California.

ISPCC (2020), "Childline answered over 70,000 contacts from children during peak Covid-19 restrictions", available at: https:/www.ispcc.ie/childline-answered-over-70000-contacts-fromchildren-during-peak-covid-19-restrictions/.

Hargreaves, A. (2020), "What's next for schools after coronavirus? Here are 5 big issues and opportunities", The Conversation, available at: https://theconversation.com/whatsnext-forschools -after-coronavirus-here-are-5-big-issues and-opportunities-135004.

Hargreaves, A. and Fullan, M. (2020), "Professional capital after the pandemic: revisiting and revising classic understandings of teachers' work", Journal of Professional Capital and Community, Vol. 5 Nos 3/4, pp. 327-336.

Harris, A. (2020), "COVID-19 - school leadership in crisis?", Journal of Professional Capital and Community, Vol. 5 Nos 3/4, pp. 321-326.

Harris, A. and Jones, M. (2020), "Covid 19 - school leadership in disruptive times", School Leadership and Management, Vol. 40 No. 4, pp. 243-247.

Howard, J.A. (2019), "A systemic framework for trauma-informed schooling: complex but necessary!", Journal of Aggression, Maltreatment and Trauma, Vol. 28 No. 5, pp. 545-565.

Jæger, M.M. and Blaabæk, E.H. (2020), "Inequality in learning opportunities during Covid-19: evidence from library takeout", Research in Social Stratification and Mobility, Vol. 68, 100524.

Kim, L.E. and Asbury, K. (2020), "Like a rug had been pulled from under you': the impact of COVID-19 on teachers in England during the first six weeks of the UK lockdown", British Journal of Educational Psychology, Vol. 90 No. 4, pp. 1062-1083.

Langford, R., Bonell, C.P., Jones, H.E., Pouliou, T., Murphy, S.M., Waters, E., Komro, K.A., Gibbs, L.F., Magnus, D. and Campbell, R. (2014), "The WHO health promoting school framework for improving the health and well-being of students and their academic achievement", Cochrane Database of Systematic Reviews, No. 4, CD008958, doi: 10.1002/14651858.CD008958.pub2.

Lawrence, N. (2020), Supervision in Education - Healthier Schools for All Barnardo's Scotland Report on the Use of Professional or Reflective Supervision in Education, Barnardo's Scotland, available at: https://www.barnardos.org.uk/sites/default/files/uploads/Supervision \% 20in \%20Education \%20-\%20Healthier \%20Schools $\% 20$ For $\% 20$ All $\% 20$ - $\% 20$ Main $\% 20$ report_0.pdf.

Leahy, D., Fitzpatrick, K. and Wright, J. (2020), Social Theory and Health Education: Forging New Insights in Research, Routledge, London.

Lee, J. (2020), "Mental health effects of school closures during COVID-19", The Lancet Child and Adolescent Health, Vol. 4 No. 6, p. 421.

Lupton, D. (2020), "Doing fieldwork in a pandemic (crowd-sourced document)", available at: https:// docs.google.com/document/d/1clGjGABB2h2qbduTgfqribHmog9B6P0NvMgVuiHZCl 8/edit? ts $=5 \mathrm{e} 88 \mathrm{ae} 0 \mathrm{a} \#$.

Marmot, M., Allen, J., Goldblatt, P., Herd, E. and Morrison, J. (2020), "Build back fairer: the COVID-19 Marmot review", The Pandemic, Socioeconomic and Health Inequalities in England, Institute of Health Equity, London. 
McCoy, S., Smyth, E., Watson, D. and Darmody, D. (2014), Leaving School in Ireland: A Longitudinal Study of Post School Transitions, ESRI, Dublin, available at: https:/www.esri.ie/system/files/ media/fileuploads/2015-07/RS36.pdf.

National Economic and Social Council (2021), "The impacts of Covid-19 on ethnic minority and migrant groups in Ireland”, available at: http://files.nesc.ie/nesc_research_series/research_ series_paper_18_Covid19Migrants.pdf.

OCO Ombudsman for Children's Office (2020), Life in Lockdown: Children's Views and Experiences of Living in Direct Provision during the Covid-19 Pandemic, Ombudsman for Children's Office.

OECD (2020), Education at a Glance, OECD, Paris.

Ontario Principal Council (2017), "Principal work-life balance and well-being matter", available at: https://www.edu.uwo.ca/faculty-profiles/docs/other/pollock/PrincipalWellBeing-17-FINAL-withAcknowledgement-1.pdf.

O’Toole, C., Maher, M. and Showunmi, V. (2018), “'Somewhere to go; someone to talk to' a report on the outcome of a consultation with young people in West Wicklow", Project Report, available at: http://mural.maynoothuniversity.ie/13912/.

O’Toole, C. and Simovska, V. (in press), "Wellbeing and education: connecting mind, body and world", in Fauchner, C., McLellan, R.W. and Simovska, V. (Eds), Wellbeing and Schooling: Cross Cultural and Cross Disciplinary Perspectives, Taylor \& Francis.

O'Toole, C. (in press), "When trauma comes to school: towards a socially just trauma- informed praxis", Special Issue, International Journal of School Social Work, Applying a Social Justice Lens to Trauma-Informed Approaches in Education.

Psychologists for Social Change (2020), "Imagining another world: why PSC is calling for us to \#BuildBackBetter from the COVID-19 crisis", available at: http://www.psychchange.org/blog/ imagining-another-world-why-psc-is-calling-for-a-justrecovery-to-the-covid-19-crisis.

Saboga-Nunes, L., Levin-Zamir, D., Bittlingmayer, U., Contu, P., Pinheiro, P. and Ivassenko, V. (2020), A Health Promotion Focus on COVID-19: Keep the Trojan Horse Out of Our Health Systems: Promote Health for All in Times of Crisis and Beyond!, International Union for Health Promotion and Education (IUHPE), Montreal.

Save the Children (2020), "Children at risk of lasting psychological distress from coronavirus lockdown", available at: https:/reliefweb.int/report/world/children-risk-lasting-psychologicaldistress-coronavirus-lockdown-save-children.

Simovska, V. (2020), "Invited talk: children's wellbeing when schools are locked down", available at: https:/www.schoolsforhealth.org/sites/default/files/editor/wellbeing-and- covid19-she-110620.pdf.

Simovska, V. and McNamara, P. (2015), Schools for Health and Sustainability, Springer, Dordrecht.

Smyth, E., McCoy, S. and Banks, J. (2019), Student, Teacher and Parent Perspectives on Senior Cycle Education, Economic and Social Research Institute, Dublin.

Spilt, J.L., Koomen, H.M. and Thijs, J.T. (2011), "Teacher wellbeing: the importance of teacher-student relationships", Educational Psychology Review, Vol. 23 No. 4, pp. 457-477.

Van Lancker, W. and Parolin, Z. (2020), "COVID-19, school closures, and child poverty: a social crisis in the making", The Lancet Public Health, Vol. 5 No. 5, pp. e243-e244.

World Health Organization WHO (1998), Global School Health Initiative. Health Promoting Schools: A Healthy Setting for Living, Learning and Working, WHO/HPR/HEP/98.4.

\section{Corresponding author}

Catriona O’Toole can be contacted at: catriona.a.otoole@mu.ie

For instructions on how to order reprints of this article, please visit our website:

www.emeraldgrouppublishing.com/licensing/reprints.htm

Or contact us for further details: permissions@emeraldinsight.com
Impact of
COVID-19 on school

communities 